\title{
Serum telomerase levels in smokers and smokeless tobacco users as Maras powder
}

\author{
Fulsen BOZKUŞ ${ }^{1}$ \\ Nurhan ATILLA 1 \\ Seçil ŞiMŞEK ${ }^{2}$ \\ Ergül KURUTAŞ ${ }^{3}$ \\ Anıl SAMUR ${ }^{4}$ \\ Hüseyin ARPAĞ ${ }^{1}$ \\ Hasan KAHRAMAN ${ }^{1}$
}

${ }^{1}$ Department of Chest Diseases, Faculty of Medicine, Kahramanmaras Sutcu Imam University, Kahramanmaras, Turkey

${ }^{1}$ Kahramanmaraş Sütçü Imam Üniversitesi Tıp Fakültesi, Göğüs Hastalıkları Anabilim Dalı, Kahramanmaraş, Türkiye

${ }^{2}$ Clinic of Biochemistry, Kahramanmaras Pazarcik State Hospital, Kahramanmaras, Turkey

${ }^{2}$ Kahramanmaraş Pazarcık Devlet Hastanesi, Biyokimya Kliniği, Kahramanmaraş, Türkiye

${ }^{3}$ Department of Medical Biochemistry, Faculty of Medicine, Kahramanmaras Sutcu Imam University, Kahramanmaras, Turkey

${ }^{3}$ Kahramanmaraş Sütçü Imam Üniversitesi Tıp Fakültesi, Tıbbi Biyokimya Anabilim Dalı, Kahramanmaraş, Türkiye

${ }^{4}$ Department of Biostatistic and Medical Informatic, Faculty of Medicine, Akdeniz University, Antalya, Turkey

${ }^{4}$ Akdeniz Üniversitesi Tıp Fakültesi, Biyoistatistik ve Tıp Bilişimi Anabilim Dalı, Antalya, Türkiye

\section{SUMMARY}

Serum telomerase levels in smokers and smokeless tobacco users as Maras powder

Introduction: To the best of our knowledge, no previous study regarding the serum telomerase levels in Maras powder users (MPUS) has been founded. The aim of the current study was to investigate serum telomerase levels in smokers and MPUs.

Materials and Methods: The study was carried out with 98 patients (36 MPUs, 32 smokers and 30 non-smokers). Blood samples were collected, and after having measured the serum telomerase and malondialdehyde (MDA) levels of the patients, comparison were made between the groups.

Results: It has been observed that the serum telomerase and MDA levels of smokers $(p<0.001)$ and MPUs $(p<0.001)$ were significantly higher compared to those of the non-smoker control subjects. In addition, the levels of serum telomerase and MDA were observed to be higher in the MPU group compared to those of the smoker group $(p<0.001)$.

Conclusion: The levels of serum telomerase and MDA were observed to be higher among MPUs and smokers. In this context, it may be useful to further measure and assess telomerase activity in such patients in order to better determine the harmful effects associated with these habits.

Key words: Maras powder, telomerase, oxidative stress

\section{Yazışma Adresi (Address for Correspondence)}

Dr. Fulsen BOZKUŞ

Kahramanmaraş Sütçü İmam Üniversitesi Tıp Fakültesi,

Göğüs Hastalıkları Anabilim Dalı,

KAHRAMANMARAŞ - TURKEY

e-mail: fulsenbatmaz@gmail.com 


\section{ÖZET}

\section{Maraş otu kullanan ve sigara içenlerde serum telomeraz düzeyleri}

Giriş: Tütün en sık sigara şeklinde yakılarak kullanılmakla birlikte doğrudan doğruya dumansız olarak çiğneme veya nasal yolla kullanımı da dünyada oldukça yaygındır. Genel adı dumansız tütün olan bu tütün ürünleri, ülkemizde de Maraş otu olarak adlandırılmaktadır. Kromozomların uçlarında yer alan telomerik yapılardan her hücresel bölünmede, bir miktar DNA kaybedilmekte ve bu kısalmanın da hücresel yaşlanmaya yol açtığı ileri sürülmektedir. Ribonükleoprotein yapıda bir enzim olan telomeraz, kendi RNA'sını kalıp olarak kullanarak sentezlediği heksomerik parçaları kromozomal uçlara ekleyerek kromozomal uçlardaki kaybı dengelemektedir. Biz de bu çalışmada sigara ile benzer kimyasalları yapısında bulunduran Maraş otu kullanıcılarında serum telomeraz ve MDA (malondialdehit) düzeylerini belirlemeyi bunu sigara içenlerle karşılaştırmayı amaçladık.

Materyal ve Metod: Çalışmaya 98 hasta dahil edildi. Bunların 36'sı Maraş otu kullanan (grup 1) 32'si sigara içen (grup 2) ve 30'u(grup 3) hiçbir tütün ürünü kullanmayan sağlıklı kontrol grubunu oluşturdu. Alınan kan örnekleri serumlarına ayrıldıktan sonra telomeraz ve MDA düzeyleri ölçüldü.

Bulgular: Sırasıyla serum telomeraz düzeyleri grup 1'de 0.38 (0.33-0.45), grup 2'de 0.32 (0.22-0.37), grup 3'te 0.15 (0.12-0.17) idi. grup 1'de ve grup 2'de ve grup 3'e göre telomeraz düzeylerinin yüksek olduğu bulundu ( $p<0.001)$. MDA düzeyleride grup 1'de 2.25 (2.14-2.44), grup 2'de 1.52 (1.45-1.63) grup 3'te 0.75 (0.62-0.87) olarak saptandı. Grup 1 ve grup 2'de MDA düzeyleri grup 3'e göre anlamlı olarak yüksek saptandı $(p<0.001)$.

Sonuç: Serum telomeraz ve MDA düzeylerinin yüksek olmasının artan oksidatif strese ve bu artışın hücresel yaşlanmaya yol açarak telomer kaybını hızlandırdığı kanaatine vardık. Maraş otunun da bir çok kronik hastalığın patogenezinde yer alan oksidatif stres artışında sigara kadar etkili olduğunu hatta daha zararlı olabileceğini düşünmekteyiz.

Anahtar kelimeler: Maraş otu, telomeraz, oksidatif stres

\section{INTRODUCTION}

Smoking is such a detrimental habit to human health that it is considered to be a health hazard in public and social dimensions. In many parts of the world such as the United States, Western Europe, Sudan, Southern Saudi Arabia and countries of Southern Africa, smokeless tobacco (ST) is widely used as an oral snuff or chewing tobacco $(1,2)$. Similarly in Kahramanmaras, a city located in southern Turkey, ST is widely used as an alternative to smoking, making this habit grow more popular gradually among the males of all ages in the region.

The word snuff refers to a large variety of products consisting mainly of finely grounded tobacco powder. Snuff usually contains various other additives as well as tobacco. Using snuff involves either placing a certain amount of powder inside the oral cavity, or inhaling the powder so that it reaches the nasal cavity (1). Depending on its method of preparation, snuff is given various different names in different parts of the world. People in Kahramanmaras have for a long time used a different variety of ST known as "Maras powder (MP)" or "oral powder" (or just "powder") (3).

However, just like the tobacco used for smoking, snuff contains an abundance of carcinogenic substances (1). Metabolites of nicotine known as tobacco specific nitrosamines (TSNAs) represent the major carcinogens in tobacco-related products $(1,3)$. Due to the formation of reactive oxygen species
(ROS) triggered, chronic inflammation can have the further enhancing carcinogenic effect associated with these nitrosamines (4). Oxidative stress is observed when the level of ROS generated by the cells exceeds the level of ROS that can be eliminated by means of the normal detoxification system, resulting in substantial damage to cellular components such as DNA (5). DNA oxidations are important due to their ability to generate mutagenesis; however, other detrimental effects such as telomere shortening, microsatellite instability, and the alteration of mitochondrial function appear to be involved in aging and cancer processes as well (6).

Telomeres are special DNA structures found precisely at the ends of the cellular chromosomes. The main function of these structures is to ensure the stability of the genome (7). The shortening of telomeres is prevented and resolved by telomerase, which is an intracellular enzyme. Each cell division of somatic cells results in the shortening of their telomeres, with the cells entering replicative senescence when the length of their telomeres eventually decreases to a certain "minimum" length $(8,9)$. Studies indicate that oxidative stress has a significant effect on the rate/ pace at which the shortening of telomeres occurs (9). This observation suggests that the levels of the enzyme telomerase may actually be associated with oxidative stress, with increased oxidative stress leading to higher serum telomerase levels. To the best of our knowledge, no study regarding the serum 
telomerase levels in Maras powder users (MPUs) has been carried out so far. In this context, the aim of the current study was to investigate the serum telomerase levels in smokers and MPUs, and to make the necessary comparisons.

\section{MATERIALS and METHODS}

\section{Study Populations}

This study based on a prospective design was performed between January 2014 and June 2014 at the Chest Diseases Department of Kahramanmaras Sutcu Imam University. All study participants were healthy male subjects registered at the chest diseases clinic of the university. The patient history of the study subjects were recorded, and their physical examinations were performed as necessary. The inclusion criteria for the study subjects were as follows: Having used Maras powder for at least 10 years, or smoked one pack of cigarettes a day for at least ten years; and age-and sex-matched nonsmokers for the control group. Patients who used both Maras powder and cigarettes were not included in the study. The age, duration of Maras powder use, and duration of smoking/cigarette use were recorded for all patients. The exclusion criteria of the study were as follows: hypertension, diabetes, congestive heart failure, chronic obstructive lung disease, malignancy, renal failure, ischemic heart disease, peripheral vascular disease, gastrointestinal disease; systemic illness, a history of having taken medications for the abovementioned diseases and a history of alcohol consumption. A total of 98 patients (36 MPUs, 32 smokers and 30 non-smokers) who met the inclusion criteria were selected and included into the study. The study was performed by adhering to the Second Declaration of Helsinki. The study was approved as necessary by the Ethics Committee of Kahramanmaras Sutcu Imam University, and informed consents were obtained from all subjects prior to their participation.

\section{Laboratory Analyses}

Blood samples were obtained from the antecubital veins of the patients in the sitting position between 08:00 and 10:00 AM. Following this, the obtained blood samples were centrifuged for 10 minutes at room temperature. Separated plasma and serum were stored at $-80^{\circ} \mathrm{C}$ until analysis. A commercial ELISA kit (Uscnlife, China) was used to evaluate the serum telomerase levels.

Serum malondialdehyde (MDA) levels were measured using spectrophotometric methods that assess the level of thiobarbituric acid reactive substances
(TBARS). Samples were prepared by adding and mixing $20 \%$ of the trichloroacetic acid and $0.67 \%$ of the thiobarbituric acid. Following this, the obtained mixtures were boiled for $30 \mathrm{~min}$ at $95^{\circ} \mathrm{C}$, after which they were immediately placed on ice for cooling. $\mathrm{N}$-butanol was then added, and the mixtures were vortexed. All vials were then centrifuged at $3000 \mathrm{~g}$ for $10 \mathrm{~min}$. Spectrophotometric measurements were then performed on the supernatant at $535 \mathrm{~nm}$. Using the extinction coefficient of $1.56 \times 10^{5} / \mathrm{moL} / \mathrm{cm}$ for the MDA-thiobarbituric acid complex, we calculated the levels of lipid peroxidation products as the MDA level.

\section{Statistical Analyses}

In this study, statistical analyses were performed using SPSS for Windows version 18.0 (SPSS Inc., Chicago, IL, USA). All categorical variables were expressed as percentages, while continuous variables from the study groups were expressed as median (IRQ). Normality tests were first performed on the numerical data, after which we used the Mann-Whitney U-test for the variables when performing two-group comparisons, and the Kruskal-Wallis test for the variables when performing three-group comparisons. Multiple comparisons were performed when statistically significant differences were observed in all groups. A p value $<0.05$ was considered to be statistically significant.

\section{RESULTS}

We measured serum telomerase and MDA levels on all of the tobacco users, which consisted of MPUs and smokers. The levels measured in MPUs and smokers were then compared with the levels in healthy controls, which consisted of non-smokers and non- MPUs. The obtained results are given in Table 1. The serum telomerase and MDA concentrations were significantly higher in the smoker $(p<0.001)$ and MPU $(p<0.001)$ groups compared to the control group. In addition, serum telomerase and MDA levels in the MPU group were higher compared to the smoker group $(p<0.001)$. The mean serum telomerase and MDA levels were found to be lowest in the control group, and the highest in the MPU group.

Figure 1 shows the distribution of serum telomerase and MDA levels according to the study groups.

\section{DISCUSSION}

Our study results demonstrated significantly higher levels of serum telomerase among smokers and 
Bozkuş F, Atilla N, Şimşek S, Kurutaş E, Samur A, Arpağ H, Kahraman H.

Table 1. General characteristics of study population

\begin{tabular}{|c|c|c|c|c|}
\hline & Maras powder $(n=36)$ & Cigarette smokers $(n=32)$ & Nontobacco users $(n=30)$ & $\mathbf{p}$ \\
\hline Gender (M/F) & $36 / 0$ & $32 / 0$ & $30 / 0$ & \\
\hline Age, years & $49(45-58.5)$ & $49(45.25-55.75)$ & $48.5(41.75-54.25)$ & 0.394 \\
\hline Tobacco use duration (year) $^{+}$ & $12(10-13)$ & $15(14-18)$ & - & 0.001 \\
\hline Telomerase activity*+ & $0.38(0.33-0.45)$ & $0.32(0.22-0.37)$ & $0.15(0.12-0.17)$ & 0.001 \\
\hline $\mathrm{MDA}^{*+}$ & $2.25(2.14-2.44)$ & $1.52(1.45-1.63)$ & $0.75(0.62-0.87)$ & 0.001 \\
\hline
\end{tabular}

MPUs. Our study is the first to specifically and concurrently evaluate the levels of serum telomerase in both smokers and MPUs.

MP can be viewed as a different smoking method. There is an erroneous notion among public that MP is not as harmful to human health as smoking (or that it is even harmless). Such products are generally preferred by those trying to lessen or quit smoking. MP is manufactured from the Nicotiana rustica Linn (NRL) species of tobacco. The leaves of this plant locally known as "crazy tobacco" -are normally grounded into a powder, which is then mixed with ash (preferably with ash from oak, walnut or grapevine wood). As a first step, the sun-dried leaves of this tobacco plant are grounded into a fine powder and mixed with ash at a ratio of approximately $1: 2$ or $1: 3$ (tobacco:ash). Following this stage, the mix is sprinkled with water for humidification. During use, a small amount of this mixture (approximately $1 \mathrm{~g}$ per intake) is placed between the lower labial mucosa and gingival areas, sometimes for 4-5 minutes, but sometimes for as long as 1-2 hours. As this area of the mouth has an extensive blood vessel as well as thin epithelia, the nicotine enters into the bloodstream very rapidly. With this method, MP can be consumed several times a day $(2,3)$.

Smoke from burning tobacco contains over 4000 different substances, one of which is nicotine, the most pharmacologically active one. Nicotine has a diverse range of cardiovascular effects, many of which are detrimental. Certain researchers also report that nicotine is a risk factor for atherosclerosis formation/development (10). High levels of serum telomerase may hence be indicative of the increased cardiovascular (CVD) risk among smokers as well as MPUs.
NRL is known to have a very high content of nicotine. For example, NRL has 6-10 times more nicotine than Nicotiana tobacum L., which is the main source of tobacco used in ordinary cigarettes (11). The results of our study demonstrated considerably higher serum telomerase levels among MPUs than among smokers. Since MP has a far higher content of nicotine than cigarettes, its detrimental effects are also likely to be more significant.

The gradual increase in life expectancy has led to the question and debate as to how the quality of life, in other words, the number of healthy years in a person's life can be increased. In the current world, one of the greatest obstacles to a healthier life-style is smoking. Furthermore, there is a strong evidence that smoking is a leading CVD risk factor (12). Evidence from experimental, epidemiological, clinical, and randomized controlled trial suggests that smoking represents one of the important risk factors for CVDs (13).

Furthermore, the possible association between aging and CVD has been a topic of considerable interest for the fields of geriatric and cardiovascular medicine. A major risk factor for atherosclerosis is aging. Aging related endothelial dysfunction is believed to be one of the elements associating aging with CVD. Atherogenic stimuli such as hypertension, smoking, diabetes, and elevated cholesterol level can induce endothelial dysfunction, which in turn can play a central role in the development of atherosclerosis. Atherosclerosis can be caused by consistent, gradual and/or repeated immunological, hemodynamic, and/ or mechanical injury -which may also involve oxidative stress -to the endothelial focal and mural regions (response-to-injury hypothesis). Such damage may result in an elevation of cell turnover in certain cell populations or tissues, causing these cells to 


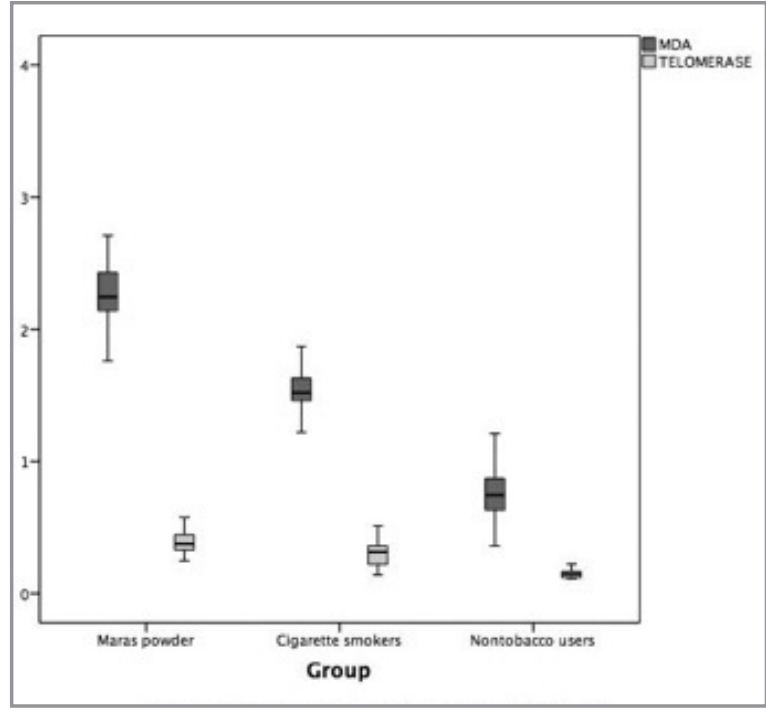

Figure 1. Distribution of serum telomerase and MDA levels.

replicate at a rate closer to their maximum replicative capacity, and to age faster as a result. It has been demonstrated that human vascular endothelial cells will lose their telomeres at a faster rate in parallel to an increase in their replication rate, and that the loss of telomere is more pronounced in tissues which are susceptible to atherogenesis. This suggests that local increases in cellular turnover rates may result in earlier cellular senescence due to more rapid telomere shortening (14). The enzyme telomerase adds telomeric repeat sequences at the ends of chromosomes, which not only serves to preserve telomere length, but also ensures healthy cellular and immune function (15). However, elevated levels of serum telomerase activity have also been described as a strong indicator of CVD risk (9).

Tobacco is believed to account for $30 \%$ of the world's cancer burden (16). Snuff contains a number of carcinogens. TSNAs, which are the most abundant carcinogens in snuff, have been shown to possess potent carcinogenic effects in experimental animal studies. In addition, snuff contains other carcinogens such as aliphatic and aromatic hydrocarbons, formaldehyde, ketones, alcohols, phenols, amines, amides, metals, radioelements (e.g., polonium-210, uranium-235 and 238) and polyaromatic hydrocarbons (1). Inside cells, these substances form covalent bonds with DNA, causing extensive DNA damage. It is believed that the biological genetoxic effect is closely associated with the dose and duration of exposure, which are important factors in determining whether the resulting DNA alteration would further lead to malignant transformations (17). Alterations and damage on DNA result in telomere loss, which in turn leads to increased telomerase activity (9). For this reason, we believe that the high serum telomerase levels observed in smokers and MPUs were possibly associated with the increased DNA damage caused by smoking and MP.

Telomerase activity tends to be high in germ and stem cells whereas it is low or non-existent in ordinary somatic cells. On the other hand, telomerase is reactivated in most tumor cells (18). The levels of telomerase activity observed in normal cells are generally lower than those in the majority of immortalized cell lines and cancer cells. The role of telomerase in ordinary cells has not been fully elucidated yet; however, it appears that telomerase activity regulation is closely associated with cell growth and differentiation (19). Telomerase activation also has the effect of inducing immortalization on normal somatic cells (20).

The majority of human cancer cells possess short telomeres whereas they also exhibit high levels of telomerase expression. On the other hand, most somatic tissues lack any significant telomerase expression (21). Numerous studies have been conducted to date on telomerase regarding its potential use as a sensitive biomarker for screening, disease prognosis or monitoring, early cancer detection, and as an indicator of residual disease associated with MP use or smoking (22).

Yim et al. recently described that telomerase activity in the mid-passage of normal human bronchial epithelial (HBE) cell cultures was higher among smokers than in non-smokers, and that a strong correlation exists between the number of pack-years and the levels of telomerase activity. Although these study results do not constitute definite evidence of a direct causative relationship, they nevertheless suggest that exposure to carcinogenic substances in tobacco may lead to a higher telomerase activity in the epithelium, thus indicating a particular molecular change associated with the alternation of these cells' lifespan (23). In our study, smokers exhibited a higher level of telomerase activity than non-smokers. Nicotine as well as other compounds in tobacco that induce intracellular oxidative stress are recognized as important agents of damage on biological molecules. 
These compounds can induce many cellular processes mediated through ROS (24). Studies on lipid peroxidation have often been adversely affected by the absence of effective biomarkers. Commonly employed biomarkers for assessing the level of lipid peroxidation level MDA plasma concentrations, since MDS is one of the various lipid peroxidation byproducts (25).

Kılınc et al. previously reported higher plasma MDA levels among MPUs in comparison to healthy controls (26). Nielsen et al. similarly determined a significant correlation between plasma MDA levels and the number of hours of exposure to cigarette smoke, but no correlation between plasma MDA levels and the number of cigarettes smoked has been found (27). In another study, cigarette smoke or MP use was found to cause an increase in salivary lactoperoxidase (LPO). The author of the said study determined that salivary MDA levels were significantly higher in the tobacco-using groups compared to the healthy controls, and also significantly higher in the MPU group compared to smoker group (28). In accordance with the literature, we determined in our study that the level of MDA was higher among MPUs and smokers.

Oxidative damages that have accumulated over the years are believed to be the main driving factor for aging and age-associated oxidative stress and diseases, as well as the cause of accelerated senescence. Studies indicate that telomeric DNA sequences are especially vulnerable to breaks in the chromosome, constituting "preferred" targets for ROS (29). Direct administration of oxidants damages DNA within cells, breaking the polyguanosine sequences in telomere repeats, causing telomere shortening, and leading to cell cycle arrest and senescence (30). Furthermore, telomeres repair single-strand breaks less efficiently than the rest of the genomic DNA (31). Oxidative stress increates the rate of telomere loss whereas antioxidants reduce it (32). In other words, increased oxidative stress is considered to be associated with the increased telomerase activity. We believe that one of the reasons for the higher levels of serum telomerase observed among the smokers and MPUs in our study was the increase in oxidative stress.

Based on the above mentioned studies and our own study findings, it is possible to state that the higher levels of serum telomerase in smokers and MPUs can very well be related to diseases such as cancers and CVDs, since both of these diseases show associations with the elevated telomerase activity as well as smoking or MP use.

\section{CONCLUSION}

Based on our study results, we can conclude that MP use and smoking are associated with the increased telomerase activity, which indicates that MP use is at least as harmful as smoking. It is possible to state that MP use is potentially more detrimental than smoking since the MPU exhibited higher serum telomerase levels than the smoking group. An important factor to consider is the fact that many chronic diseases associated with the harmful effects and damages of both smoking and MP usually occur later in life, in advanced ages. Studies performed in recent years have pointed to the essential role telomeres and telomerase assume in processes associated with cellular aging and diseases. The aging process involves a sequence of progressive changes at cellular level, which eventually lead to death; however, the mechanisms associated with aging have not been elucidated yet. The search for the genes involved in aging processes - as well as understanding the factor that will ensure longevity -has been an area of considerable interest for biomedical research for a long time (33). The results of this study are also significant in that they draw attention to a potential public health hazard -namely the use of Maras powder. However, we believe that further studies with larger samples should be conducted in order to further expand and elaborate the results of the present study.

\section{CONFLICT of INTEREST}

All of the authors of this manuscript declare that they have no conflicts of interest.

\section{REFERENCES}

1. Idris AM, Ibrahim SO, Vasstrand EN, Johannessen AC, Lillehaug JR, Magnusson B, et al. The Swedish snus and the Sudanese toombak: are they different? Oral Oncol 1998:34:558-66.

2. Kurtul N, Cil MY, Pacaci SD. Serum total sialic acid levels in smokers and users of smokeless tobacco in form of oral powder (Maras powder). J Biomed Sci 2005;12:559-63.

3. Weitberg $A B$, Corvese $D$. The effect of epigallocatechin galleate and sarcophytol $A$ on DNA strand breakage 
induced by tobacco-specific nitrosamines and stimulated human phagocytes. J Exp Clin Cancer Res 1999;18:433-7.

4. Mozaffarieh M, Konieczka K, Hauenstein D, Schoetzau A, Flammer J. Half a pack of cigarettes a day more than doubles DNA breaks in circulating leukocytes. Tob Induc Dis 2010;8:14.

5. Evans MD, Dizdarog/u M, Cooke MS. Oxidative DNA damage and disease: induction, repair and significance. Mutat Res 2004;567:1-61.

6. Zhu H, Belcher M, Harst P. Healthy aging and disease: role for telomere biology? Clin Sci (Lond) 2011;120:427-40.

7. Von Zglinicki T. Telomeres and replicative senescence: is it only length that counts? Cancer Lett 2001;168:111-6.

8. Joosten SA, van Ham V, Nolan CE, Borrias MC, Jardine AG, Shiels PG, et al. Telomere shortening and cellular senescence. Am J Pathol 2003;162:1305-12.

9. Balasubramanyam M, Adaikalakoteswari A, Monickaraj SF, Mohan V. Telomere shortening \& metabolic/vascular diseases. Indian I Med Res 2007; 125:441-50.

10. Latha SM, Vijayammal PL, Kurup PA. Effect of nicotine administration on lipid metabolism in rats. Indian I Med Res 1993;98:44-9.

11. Saitoh F, Noma M, Kawashima N. The alkaloid contents of sixty Nicotiana species. Phytochemistry 1985;24:477-80.

12. World Health Organization. WHO Report on Global Tobacco Epidemic: Warning about Dangers of Tobacco. Geneva: World Health Organization; 2011.

13. Gupta R, Gupta N, Khedar RS. Smokeless tobacco and cardiovascular disease in low and middle income countries. Indian Heart / 2013;65:369-77.

14. Chang E, Harley CB. Telomere length and replicative aging in human vascular tissues. Proc Natl Acad Sci USA 1995;92:11190-4.

15. Blackburn EH. Telomere states and cell fates. Nature 2000;40:53-6.

16. Nair U, Bartsch H, Nair J. Alert for an epidemic of oral cancer due to use of the betel quid substitutes gutkha and pan masala: a review of agents and causative mechanisms. Mutagenesis 2004;19:251-62.

17. Ohnishi S, Murat M, Kawanishi S. Oxidative DNA damage induced by a metabolite of 2-naphthylamine, a smoking related bladder carcinogen. Jpn J Cancer Res 2002;93:73643.

18. Yashima K, Litzky LA, Kaiser L, Rogers T, Lam S, Wistuba II, et al. Telomerase expression in respiratory epithelium during the multistage pathogenesis of lung carcinomas. Cancer Res 1997;57:2373-7.

19. Kunimura C, Kikuchi K, Ahmed N, Shimizu A, Yasumoto S. Telomerase activity in a specific cell subset coexpressing integrinbeta1/EGFR but not p75NGFR/bcl2/integrin beta4 in normal human epithelial cells. Oncogene 1998;17:187-97.
20. Lundberg AS, Randell SH, Stewart SA, Elenbaas B, Hartwell $K A$, Brooks MW, et al. Immortalization and transformation of primary human airway epithelial cells by gene transfer. Oncogene 2002;21:4577-86.

21. Shay IW, Bacchetti S. A survey of telomerase activity in human cancer. Eur I Cancer 1997:33:787-91.

22. Shay IW, Gazdar AF. Telomerase in the early detection of cancer. J Clin Pathol 1997;50:106-9.

23. Yim HW, Slebos RI, Randell SH, Umbach DM, Parsons AM, Rivera MP, et al. Smoking is associated with increased telomerase activity in short-term cultures of human bronchial epithelial cells. Cancer Lett 2007;246:24-33.

24. Barr J, Sharma CS, Sarkar S, Wise K, Dong L, Periyakaruppan $A$, et al. Nicotine induces oxidative stress and activates nuclear transcription factor kappa $B$ in rat mesencephalic cells. Mol Cell Biochem 2007;297:93-9.

25. Church DF, Pryor WA. Free-radical chemistry of cigarette smoke and its toxicological implications. Environ Health Perspect 1985;64:111-26.

26. Kılınc M, Okur E, Kurutas EB, Guler FI, Yıldırım I. The effects of Maras powder (smokeless tobacco) on oxidative stress in users. Cell Biochem Funct 2004:22:233-6.

27. Nielsen F, Mikkelsen BB, Nielsen JB, Andersen HR, Grandjean P. Plasma malondialdehyde as biomarker for oxidative stress: reference interval and effects of life-style factors. Clin Chem 1997;43:1209-14.

28. Kurtul N, Gokpınar E. Salivary lipid peroxidation and total sialic acid levels in smokers and smokeless tobacco users as Maraş powder. Mediators Inflamm 2012;2012:619293.

29. Henle ES, Han Z, Tang N, Rai P, Luo Y, Linn S. Sequencespecific DNA cleavage by Fe2+-mediated fenton reactions has possible biological implications. I Biol Chem 1999;274:962-71.

30. Oikawa S, Kawanishi S. Site-specific DNA damage at GGG sequence by oxidative stress may accelerate telomere shortening. FEBS Lett 1999;453:365-8.

31. Petersen S, Saretzki G, von Zglinicki T. Preferential accumulation of single-stranded regions in telomeres of human fibroblasts. Exp Cell Res 1998;239:152-60.

32. von Zglinicki T. Oxidative stress shortens telomeres. Trends Biochem Sci 2002;27:339-44.

33. Liu JP. Studies of the molecular mechanisms in the regulation of telomerase activity. FASEB J 1999;13:2091104. 